\title{
PEMANFAATAN MONYET EKOR PANJANG (Macaca fascicularis) SEBAGAI WISATA EDUKASI DI BABAKAN, SUMBER, CIREBON
}

\author{
Juju Juwita ${ }^{1)}$, Muhimatul Umami ${ }^{2)}$ \\ ${ }^{1,2}$ Jurusan Tadris Biologi, IAIN Syekh Nurjati Cirebon \\ Email $^{1)}$ :jj.juwita2109@mail.syekhnurjati.ac.id \\ Email ${ }^{2}$ : muhimatul.umami@syekhnurjati.ac.id
}

\begin{abstract}
ABSTRAK : Wisata edukasi merupakan salah satu jenis wisata yang biasanya dikunjungi oleh para wisatawan untuk tujuan pembelajaran. Salah satu objek wisata edukasi yaitu objek wisata Plangon yang berlokasi di Kelurahan Babakan Kecamatan Sumber Kabupaten Cirebon. Di objek wisata Plangon tersebut terdapat salah satu spesies hewan dari kelas Mamalia, ordo Primata dan famili Cercopithecidae yaitu Macaca fascicularis atau monyet ekor panjang, dengan karakteristik khususnya yaitu memiliki ekor yang panjang dan sebagian besar tubuhnya ditutupi oleh rambut berwarna abu-abu hingga cokelat keabuan. Adapun tujuan dari penelitian ini yaitu untuk mengetahui pemanfaatan monyet ekor panjang (Macaca fascicularis) sebagai wisata edukasi di Kelurahan Babakan, Kecamatan Sumber, Kabupaten Cirebon. Metode penelitian adalah metode kualitatif dan data hasil penelitian disajikan secara deskriptif, penelitian dilakukan dengan mengobservasi langsung objek wisata Plangon dan melalui wawancara dengan narasumber yaitu juru kunci Plangon untuk mendapatkan data primer dan data sekunder didapatkan melalui proses studi literatur dengan mencari referensi yang relevan dari berbagai macam artikel atau jurnal terkait hal tersebut. Populasi monyet ekor panjang (Macaca fascicularis) di kawasan objek wisata Plangon cukup banyak sehingga berpotensi untuk dimanfaatkan sebagai wisata edukasi, dengan adanya pemanfaatan spesies ini para pengunjung akan mempelajari mengenai perilaku, karakteristik serta aktivitas yang dilakukan oleh spesies tersebut di kawasan objek wisata Plangon. Selain itu adanya pemanfaatan spesies ini sebagai wisata edukasi juga dapat berperan dalam penelitian di bidang ekologi maupun zoologi.
\end{abstract}

Kata kunci: wisata edukasi, monyet ekor panjang, pemanfaatan

ABSTRACT: Educational tourism is one type of tourism that is usually visited by tourists for learning purposes. One of the educational tourism objects is Plangon tourism which is located in Babakan Village, Sumber District, Cirebon Regency. At the Plangon tourist attraction, there is one species of animal from the class Mammals, order Primates and family Cercopithecidae, namely Macaca fascicularis or long-tailed monkeys, with special characteristics of having a long tail and most of its body covered by gray to gray-brown hair. The purpose of this study was to determine the use of long-tailed monkeys (Macaca fascicularis) as educational tourism in Babakan Village, Sumber District, Cirebon Regency. The research method is a qualitative method and the research data is presented descriptively, the research is carried out by direct observation of Plangon tourism objects and through interviews with resource persons, namely Plangon caretakers to obtain primary data and secondary data obtained through a literature study process by looking for relevant references from various kinds. articles or journals related to it. The population of long-tailed monkeys (Macaca fascicularis) in the Plangon tourist attraction area is quite large so that it has the potential to be used 
as an educational tour. With the use of this species, visitors will learn about the behavior, characteristics and activities carried out by these species in the Plangon tourist attraction area. In addition, the use of this species as educational tourism can also play a role in research in the fields of ecology and zoology.

Keywords: educational tourism, long-tailed monkeys, utilization

\section{PENDAHULUAN}

Wisata merupakan kegiatan mengunjungi suatu tempat tertentu dalam hal ini objek wisata atau tempat wisata, biasanya dilakukan dengan tujuan untuk rekreasi atau mempelajari daya tarik di tempat yang dikunjungi tersebut dan berlangsung dalam jangka waktu yang tidak lama atau sementara. Objek wisata atau tempat wisata kerap kali digunakan untuk melepaskan penat dari aktivitas sehari-hari yang dilakukan. Keberadaan objek wisata atau tempat wisata di suatu daerah menjadikan daerah tersebut memiliki ciri khas tersendiri yang dikenal oleh masyarakat, keberadaan objek wisata di suatu daerah juga memberikan keuntungan seperti dapat meningkatkan lapangan pekerjaan, meningkatkan penghasilan masyarakat sekitar tempat wisata tersebut juga turut serta dalam melestarikan budaya yang ada di daerah tersebut. Hal tersebut juga sesuai dengan pernyataan Sandy (2018) bahwa adanya objek wisata di suatu daerah akan sangat menguntungkan, hal tersebut karena dapat meningkatkan kondisi ekonomi masyarakat, meningkatkan kesempatan kerja, melestarikan alam dan budaya setempat juga meningkatkan rasa cinta terhadap lingkungan. Salah satu jenis wisata adalah wisata edukasi atau disebut juga dengan educational tourism.

Educational tourism atau wisata edukasi adalah jenis wisata yang dilakukan dengan mendatangi (mengunjungi) objek wisata untuk mendapatkan pengalaman pembelajaran secara langsung di objek wisata tersebut. Sebagaimana disampaikan oleh Devi, et al., (2019) bahwa wisata edukasi atau educational tourism merupakan suatu program yang dilakukan oleh wisatawan dengan berkunjung ke suatu tempat wisata dengan tujuan utamanya untuk memperoleh pengalaman belajar langsung di tempat wisata yang dikunjungi. Sehingga berdasarkan hal tersebut, wisata edukasi dapat dideskripsikan sebagai wisata yang mengkombinasikan atau menggabungkan aktivitas rekreasi dan pendidikan sebagai salah satu produk pariwisata yang mengandung unsur pembelajaran. Menurut Ekasani et al., (2020) wisata edukasi dapat dikategorikan menjadi beberapa jenis di antaranya wisata edukasi mengenai budaya, sejarah, ekowisata atau wisata edukasi berbasis lingkungan, wisata pedesaan, maupun program studi di luar negeri. Dalam wisata edukasi juga terdapat adanya kegiatan berupa long learning atau kegiatan yang dilakukan demi pembelajaran untuk meningkatkan kompetensi atau keterampilan. Salah satu objek wisata berbasis edukasi adalah objek wisata Plangon.

Objek wisata Plangon merupakan tempat wisata edukasi berbasis sejarah dan lingkungan alam yang masih asri. Lokasi objek wisata ini tidak begitu jauh dari pusat pemerintahan Kabupaten Cirebon yaitu kurang dari dua kilometer. Jika dilihat dari wilayah administratifnya objek wisata ini terletak di Jalan Pangeran Kejaksan, Kelurahan Babakan, Kecamatan Sumber, Kabupaten Cirebon. Kawasan

Bio-Lectura: Jurnal Pendidikan Biologi, Vol 8, No 2,Oktober 2021 
objek wisata Plangon dikelilingi oleh hutan lebat dengan ratusan monyet ekor panjang (Macaca fascicularis) yang mendiami wilayah tersebut. Uniknya monyet-monyet tersebut tidak buas terlebih jika pengunjung didampingi oleh sejumlah pemandu objek wisata lokal ketika mengunjungi tempat ini. Sebagai objek wisata berbasis edukasi, Plangon memiliki nilai-nilai sejarah karena di objek wisata ini terdapat makam Pangeran Kejaksan dan Pangeran Panjunan, kedua tokoh tersebut merupakan tokoh yang dianggap paling berpengaruh dan juga berjasa dalam penyebaran agama islam di Cirebon terutama di wilayah Sumber.

Menurut Siswoyo, et al., (2019) berdasarkan Babad Cirebon, Pangeran Panjunan dan Pangeran Kejaksan atau Syarif Abdurrahman dan Syarif Abdurrahim adalah putra dari Sultan Baghdad yang pergi berlayar ke Cirebon untuk menuntut ilmu dan juga berguru kepada Syekh Nurjati kemudian diperkenalkan kepada Pangeran Cakrabuana. Syarif Abdurrahman ditugaskan oleh Pangeran Cakrabuana di wilayah Panjunan sedangkan Syarif Abdurrahim ditugaskan ke wilayah Kejaksan. Selain itu nilai edukasi pada objek wisata Plangon ini juga berbasis lingkungan alam di mana terdapat berbagai jenis tumbuhan yang berperan dalam kajian botani juga terdapat berbagai jenis hewan dan yang mendominasi adalah monyet ekor panjang (Macaca fascicularis) sebagai objek kajian dalam bidang zoologi. Macaca fascicularis atau monyet ekor panjang yang jumlahnya cukup mendominasi dan menjadi ciri khas tersendiri di objek wisata Plangon ini memiliki peranan tertentu, seperti dalam bidang edukasi atau pendidikan, dengan adanya objek wisata edukasi Plangon pengunjung tidak hanya mempelajari sejarah saja namun juga dapat mengamati dan mempelajari mengenai monyet ekor panjang (Macaca fascicularis) yang merupakan salah satu spesies kelas Mamalia dari ordo Primata, baik itu perilakunya, karakteristiknya, maupun peranannya. Jumlahnya yang banyak menjadikan monyet jenis ini saling menghimpun diri dalam beberapa kelompok guna mempertahankan diri. Persebaran kelompok monyet ekor panjang (Macaca fascicularis) menurut Sembiring, et al., (2016) dipengaruhi oleh sumber pakan, sumber air, keberadaan satwa lain juga keberadaan manusia. Berdasarkan hal tersebut maka tujuan dari penelitian ini adalah untuk mendeskripsikan mengenai pemanfaatan monyet ekor panjang (Macaca fascicularis) sebagai wisata edukasi di objek wisata Plangon.

\section{METODE PENELITIAN}

Metode penelitian yang digunakan adalah penelitian kualitatif. Sumber data pada penelitian ini berupa data primer dan data sekunder. Data primer didapatkan dari kegiatan observasi secara langsung di objek wisata Plangon dan data hasil wawancara dengan juru kunci objek wisata Plangon. Sedangkan data sekunder didapatkan melalui studi literatur terhadap berbagai artikel atau jurnal maupun buku yang berkaitan dengan penelitian. Untuk memperoleh data primer pada penelitian ini, observasi di lokasi objek wisata Plangon dilakukan pada tanggal 15 Mei 2021 pukul 09.00 WIB s.d. pukul 10.30 WIB untuk memperoleh data mengenai karakteristik serta pemanfaatan monyet ekor panjang (Macaca fascicularis). Sedangkan untuk proses wawancara 
dilakukan pada tanggal 20 Mei 2021 pukul 11.30 WIB s.d. 12.15 WIB di kediaman juru kunci objek wisata Plangon. Proses wawancara dilakukan untuk mendapatkan data mengenai sejarah dari objek wisata Plangon, juga peranan dan pemanfaatan monyet ekor panjang (Macaca fascicularis) dari sudut pandang narasumber.

Adapun untuk memperoleh data dari studi literatur dilakukan dengan cara mencari jurnal atau artikel yang relevan dengan permasalahan yang dikaji. Proses identifikasi dilakukan dengan mencari jurnal-jurnal ataupun artikel terkait dengan permasalahan yang dikaji pada laman pencarian di website Google Scholar maupun laman pencarian website lainnya yang biasa digunakan untuk mencari jurnal-jurnal dan artikel ilmiah, dengan publikasi dimulai tahun 2015, setelah itu tahap penyaringan atau kelayakan, semua artikel yang telah diidentifikasi berdasarkan relevansi topik diunduh, selanjutnya jurnal-jurnal yang memenuhi syarat dipelajari dan dianalisis dan digunakan untuk melengkapi data hasil penelitian. Data hasil penelitian tersebut dianalisis secara deskriptif.

\section{HASIL DAN PEMBAHASAN 3.1 Sejarah Singkat Plangon}

Berdasarkan hasil wawancara yang telah dilaksanakan bersama narasumber yaitu juru kunci objek wisata Plangon bernama Bapak Zesta Yanderaz Shagystar, sejarah Plangon dimulai ketika Syekh Abdurrahman dan Syekh Abdurrahim yang berasal dari Baghdad Irak, putras dari Raja Sulaeman bin Hud yang masih keturunan dari Nabi Muhammad SAW., kedua putra Raja Sulaeman ini datang ke Cirebon untuk menuntut ilmu dan ditugaskan untuk menyampaikan syiar islam. Dahulunya nama Plangon bernama Giri Toba.
Syekh Abdurrahman dan Syekh Abdurrahim juga dikenal dengan Pangeran Panjunan dan Pangeran Kejaksan, sebelum datang ke Plangon kedua Syekh tersebut diberi julukan Syekh Maulana Maghribi, kemudian nama Pangeran Panjunan dan Pangeran Kejaksan didapatkan setelah beliau datang ke wilayah Plangon yang sebelumnya bernama Giri Toba. Nama Plangon yang sekarang kita kenal juga merupakan pemberian dari syekh tersebut. Kata Plangon berasal dari kata tegal nglangen atau klangenan yang memiliki arti sebagai tempat yang damai, tentram, asri, dan seiring berjalannya waktu supaya memudahkan penyebutan kata tersebut, maka kata tegal nglangen atau klangenan berubah menjadi Plangon hingga saat ini. Menurut Norantica, et al., (2020) sejarah Plangon ini benar adanya namun tidak begitu dikembangkan karena cerita sejarah mengenai Plangon bersifat turun temurun dan hanya diwariskan kepada juru kunci atau kuncen Plangon saja. Sehingga cerita sejarah dari tempat ini memiliki beberapa versi sejarah dari berbagai pihak.

3.2 Asal-usul Monyet Ekor Panjang (Macaca fascicularis) Plangon

Monyet ekor panjang (Macaca fascicularis) yang berada di objek wisata Plangon berasal dari Aceh. Berdasarkan penuturan narasumber, monyet-monyet tersebut merupakan hadiah yang diberikan oleh Raja Kesultanan Samudra Pasai. Sebelum sampai di Cirebon Syekh Abdurrahman singgah terlebih dahulu di Kesultanan Pasai yang merupakan kerajaan islam yang terletak di pesisir pantai utara Sumatera, Provinsi Aceh Indonesia. Ketika akan berpamitan untuk melanjutkan perjalanan saat itu pula Syekh Abdurrahman diberi hadiah berupa dua ekor monyet ekor panjang 
(Macaca fascicularis) masing-masing berjenis kelamin jantan dan betina. Sehingga seiring berjalannya waktu spesies hewan tersebut terus berkembang biak dan jumlahnya cukup banyak di objek wisata Plangon ini. Namun monyet jenis ini tidak hanya hidup di kawasan objek wisata Plangon saja melainkan di berbagai daerah di Indonesia juga monyet jenis ini dapat ditemukan. Hal tersebut karena monyet ekor panjang (Macaca fascicularis) memiliki penyebaran wilayah yang luas.

Menurut Hadi, et al., (2019) Macaca fascicularis adalah primata yang mempunyai persebaran wilayah luas. Spesies ini hidup di daratan Asia Tenggara, seperti Kepulauan Sunda, Filipina, monyet jenis ini juga dapat ditemukan di wilayah Kepulauan Sunda Kecil yaitu wilayah Nusa Tenggara Timur dan Nusa Tenggara Barat. Bahkan di wilayah Nikobar, Mauritius, Angaur, Papua juga dapat ditemukan monyet jenis ini. Kesuksesan penyebaran monyet ekor panjang (Macaca fascicularis) pada berbagai wilayah geografi yang luas disebabkan karena monyet jenis ini mempunyai kemampuan adaptasi yang baik terhadap lingkungan. Hal tersebut bersesuaian dengan pernyataan Syah (2020) bahwa Macaca fascicularis (monyet ekor panjang) adalah spesies primata yang sangat adaptif terhadap berbagai macam habitat. Spesies ini dapat ditemukan di kawasan kanopi hutan, hutan bersungai, kawasan pesisir, mangrove, rawa maupun hutan wisata.

\subsection{Karakteristik Monyet Ekor} Panjang (Macaca fascicularis) Plangon

Macaca fascicularis (monyet ekor panjang) sebagai satwa yang jumlahnya cukup banyak di objek wisata Plangon, memiliki karakteristik morfologi sebagaimana Macaca fascicularis (monyet ekor panjang) pada umumnya. Karakteristik Macaca fascicularis (monyet ekor panjang) yang ada di objek wisata Plangon di antaranya hampir seluruh tubuhnya tertutupi oleh rambut berwarna cokelat keabuan dan ada juga yang berwarna cokelat kemerahan. Ekornya panjang berbentuk bulat silindris dan ditutupi oleh rambut berukuran pendek dengan warna yang serupa seperti warna rambut pada tubuhnya, hidungnya datar pada bagian pangkal dan menyempit pada bagian ujungnya, memiliki kelenjar mamae, memiliki alat gerak berupa empat kaki yang digunakan untuk berjalan, melompat berpindah dari satu dahan ke dahan lain, maupun untuk mengambil makanan. Pada bagian kepala juga terkadang terdapat jambul, pada bagian wajahnya terdapat jambang.

Hal tersebut sesuai dengan yang disampaikan oleh Halim (2019) bahwa Macaca fascicularis (monyet ekor panjang) merupakan salah satu jenis hewan dari kelas Mamalia, ordo primata dan famili Cercopithecidae yang memiliki ciri berupa warna tubuh yang beranekaragam mulai dari keabuan hingga cokelat. Bagian dorsal tubuh umumnya berwarna lebih gelap jika dibandingkan dengan bagian ventral tubuhnya, ekornya panjang dan tertutupi oleh rambut halus berukuran pendek. Rambut di bagian kepala dan di sekeliling wajah spesies ini membentuk jambang lebat. Pada umumnya monyet yang baru lahir atau monyet anakan memiliki warna rambut yang hitam pada bagian kepalanya. Macaca fascicularis (monyet ekor panjang) juga merupakan jenis hewan yang hidup berkelompok atau arboreal. (Anggraini, et al., 2019). Hal ini sesuai dengan keadaan yang ada pada Macaca fascicularis (monyet ekor panjang) di 
Plangon, di mana monyet-monyet tersebut hidup membentuk kolonikoloni tertentu dan memiliki batas wilayahnya masing-masing, setiap kelompok monyet yang ada di wilayah tersebut tidak saling mengganggu maupun memasuki wilayah lainnya. Berikut adalah klasifikasi ilmiah dari Macaca fascicularis (monyet ekor panjang) yang ada di kawasan objek wisata Plangon:

$\begin{array}{ll}\text { Kingdom } & \text { : Animalia } \\ \text { Filum } & \text { : Chordata } \\ \text { Subphylum } & \text { : Vertebrata } \\ \text { Kelas } & \text { : Mamalia } \\ \text { Ordo } & \text { : Primata } \\ \text { Famili } & \text { : Cercopithecidae } \\ \text { Genus } & \text { : Macaca } \\ \text { Spesies } & : \text { Macaca fascicularis } \\ \text { Author } & \text { : Raffles, 1821 }\end{array}$

Macaca fascicularis (monyet ekor panjang) yang ada di objek wisata Plangon juga memiliki aktivitas harian sebagaimana hewan lainnya, baik itu perilaku mencari makan, bergerak, perilaku seksual, dll. Menurut Fachrozi dan Setyawatiningsih (2020) beberapa perilaku yang biasanya ada pada hewan di antaranya perilaku makan yang mencakup mencari makan, membawa makanan, dan memasukkan makanan ke dalam mulut. Dari pengamatan pada Macaca fascicularis yang ada di Plangon perilaku makan yang dilakukan oleh spesies tersebut berupa membawa makanan menggunakan tangannya dan memasukkan makanan ke dalam mulutnya dengan cara membuka kulit kacang yang diberikan menggunakan giginya. Ada juga perilaku istirahat mencakup perilaku tidur dan tidak bergerak, dari pengamatan pada Macaca fascicularis yang ada di Plangon ketika dilakukan pengamatan tidak ada spesies yang sedang melakukan istirahat, semua spesies tersebut sedang aktif melakukan aktivitas lain. Jenis perilaku yang berikutnya adalah perilaku berpindah, berupa berlari, berjalan, memanjat maupun melompat. Ketika observasi berlangsung sebagian besar Macaca fascicularis yang ada di Plangon sedang melakukan aktivitas ini, berlari dan berjalan menggunakan kakinya, maupun memanjat dan melompat dari satu dahan pohon ke dahan pohon lainnya. Selain itu ada juga perilaku menelisik dan perilaku bermain. Perilaku menelisik biasanya meliputi aktivitas mengambil atau mencari parasite maupun kotoran di tubuh monyet tersebut dengan menggunakan mulut atau tangan baik dilakukan sendiri maupun bersama individu lainnya. Sedangkan perilaku bermain dapat berupa bergelantungan, saling mengejar. Terdapat juga perilaku agresif seperti berkelahi, menghindar, menantang yang dilakukan pada individu lain. Ada juga perilaku seksual, atau perilaku di mana hewan jantan dan betina melakukan proses kawin, namun perilaku ini tidak teramati pada saat observasi berlangsung, karena biasanya perilaku seksual ini terjadi di waktu-waktu tertentu. Hal tersebut karena monyet ekor panjang memiliki sistem reproduksi berupa polygyny di mana hewan betina dan jantan dapat mempunyai pasangan lebih dari satu pasangan. Spesies ini juga hidup berkelompok dengan sistem multifemale dan multimale, keberhasilan reproduksi dari spesies ini bergantung pada kondisi fisik monyet tersebut, hirarkinya, juga faktor lingkungan seperti ketersediaan makanan. (Nabilah, et al., 2019).

3.4 Interaksi Masyarakat dalam Memanfaatkan Monyet Ekor Panjang (Macaca fascicularis) Plangon

Keberadaan objek wisata Plangon sebagai objek wisata edukasi turut 
membantu

mengembangkan

perekonomian masyarakat sekitar. Pada umumnya masayarakat sekitar biasanya berjualan di kawasan objek wisata Plangon tersebut. Keberadaan Macaca fascicularis (monyet ekor panjang) di kawasan objek wisata Plangon dengan jumlah yang cukup banyak membuat masyarakat sekitar berinisiatif untuk menjual makanan monyet tersebut kepada para pengunjung yang akan melakukan wisata di objek wisata ini. Para penjual tersebut biasanya menjual kacang dan juga pisang untuk ditawarkan kepada pengunjung yang akan melakukan wisata. Selain itu dengan adanya monyet tersebut, beberapa warga menjadi pemandu wisata bagi para pengunjung, karena pada umumnya pengunjung yang baru pertama kali mengunjungi tempat ini akan langsung disambut oleh kawanan Macaca fascicularis (monyet ekor panjang) sehingga akan menimbulkan rasa takut, namun jika kita berkunjung di objek wisata ini dipandu oleh pemandu wisata tersebut maka secara tidak langsung kita akan merasa nyaman, karena monyet-monyet yang ada di kawasan objek wisata ini sudah terbiasa berinteraksi dengan pemandu wisata.

Macaca fascicularis (monyet ekor panjang) yang ada di objek wisata Plangon sebagaimana hewan lainnya memiliki peranan tersendiri di tempat tersebut. Pemanfaatan spesies ini, termasuk sebagai wisata edukasi seperti yang ada di objek wisata Plangon, dengan adanya spesies ini akan menambah daya tarik tersendiri bagi para pengunjung, dalam melakukan wisata edukasi di objek wisata Plangon pengunjung tidak hanya dapat mempelajari sejarah saja melainkan dapat mempelajari dari segi cabang ilmu lainnya khususnya mengenai hewan karena adanya spesies
Macaca fascicularis (monyet ekor panjang). Keberadaan spesies ini juga turut membantu menyeimbangkan ekosistem. Adanya Macaca fascicularis (monyet ekor panjang) sebagai wisata edukasi ini kita dapat dengan mudah mengamati dan mempelajari mengenai karakteristik, habitat, aktivitas harian maupun perilaku dari spesies ini serta interaksinya terhadap spesies lain maupun dengan sesamanya, namun tentunya karena adanya objek wisata edukasi yang Macaca fascicularis (monyet ekor panjang)ini tidak menutup kemungkinan terjadinya perbedaan karakter baik itu perilaku maupun aktivitas harian yang ditunjukkannya dengan spesies yang sama yang hidup liar di hutan.

Menurut Nugraha, et al., (2018) keberadaan Macaca fascicularis atau monyet ekor panjang memiliki peranan dan makna tersendiri seperti dalam nilai estetika, ekologi, keilmuan maupun nilai rekreasi. Sedangkan menurut Rizaldy, et al., (2016) sebagai primata arboreal, Macaca fascicularis (monyet ekor panjang) memiliki peranan penting bagi hutan yaitu berperan dalam regenerasi hutan tropik. Sebagaimana kita ketahui sebagian besar Macaca fascicularis (monyet ekor panjang) memakan biji-bijian maupun buah-buahan yang ada di hutan sehingga turut berperan dalam penyebaran biji-bijian tersebut. Macaca fascicularis (monyet ekor panjang) juga berperan dalam pengendalian populasi serangga di suatu ekosistem karena hewan ini merupakan hewan opportunistic omnivore atau hewan pemakan berbagai jenis makanan seperti, daging, buah, serangga, dan sebagainya. Peranan Macaca fascicularis (monyet ekor panjang) yang lainnya misalnya di bidang ekonomi, dapat dimanfaatkan 
sebagai pemetik buah kelapa maupun pertunjukan topeng monyet, di bidang etnozoologi spesies ini dimanfaatkan dagingnya sebagai sumber protein bagi manusia. (Fachrozi dan Setyawatiningsih, 2020). Selain itu spesies ini juga berperan dalam bidang medis, digunakan sebagai hewan percobaan atau hewan model percobaan obat-obatan. (Tan, et al., 2018). Namun karena cukup banyaknya pemanfaatan Macaca fascicularis (monyet ekor panjang) dan statusnya belum dilindungi, maka spesies ini cenderung sering diburu.

\section{KESIMPULAN}

Pemanfaatan monyet ekor panjang (Macaca fascicularis) sebagai wisata edukasi di Kelurahan Babakan Kecamatan Sumber Kabupaten Cirebon memiliki peranannya tersendiri, masyarakat sekitar objek wisata memanfaatkan peluang untuk meningkatkan ekonomi dengan cara berjualan di sekitar objek wisata Plangon, keberadaan monyet ekor panjang di objek wisata Plangon juga dimanfaatkan sebagai ladang untuk mencari penghasilan dengan menjadi pemandu wisata di objek wisata ini, dengan adanya pemanfaatan spesies ini para pengunjung akan mempelajari mengenai perilaku, karakteristik serta aktivitas yang dilakukan oleh spesies tersebut di kawasan objek wisata Plangon. Selain itu adanya pemanfaatan spesies ini sebagai wisata edukasi juga dapat berperan dalam penelitian di bidang ekologi maupun zoologi, karena hewan ini statusnya belum dilindungi maka tidak menutup kemungkinan spesies ini akan sering diburu oleh manusia untuk dimanfaatkan dalam bidang lainnya. Karena jika keberadaan populasi spesies ini terganggu juga akan berpengaruh terhadap ekosistem yang ada di objek wisata tersebut, untuk itu keberadaan monyet ekor panjang (Macaca fascicularis) di kawasan objek wisata Plangon ini perlu dimanfaatkan seoptimal mungkin tanpa mengganggu jumlah populasi dari spesies hewan ini.

\section{DAFTAR PUSTAKA}

Anggraini, F., D., Prasetyo, A., P., B., dan Iswari, R., S. (2019). Promoting Children's Conservation Awareness of Macaca fascicularis Through Narrative Video. USEJ: Unnes Science Educational Journal. 8(3): 370 .

http://journal.unnes.ac.id/sju/index .php/usej

Devi, Ida., A., S., Damiati dan Adnyawati, Ni., D., M., S. (2018). Potensi Objek Wisata Edukasi di Kabupaten Gianyar. Jurnal Bosaparis: Pendidikan Kesejahteraan Keluarga. 9(1): 132.

DOI: $10.23887 /$ jjpkk.v9i2.22136

Ekasani, K., A., Bhuanaputri, Ni., K., A., W., Yosephanny, P., dan Alberta, F., J. (2020). The Role of Educational Tourism for Indonesian Development. Journal of Business on Hospitality and Tourism. 6(2): 171-172. https://dx.doi.org/10.22334/jbhost. $\underline{\mathrm{v} 6 \mathrm{i} 2}$

Fachrozi, I., dan Setyawatiningsih, S., C. (2020). Perilaku Harian Monyet Ekor Panjang (Macaca fascicularis) di Arboretum 
Universitas Riau (UNRI) dan

Sekitarnya. AL-KAUNIYAH:

Jurnal Biologi. 13(2): 149.

https://doi.org/10.15408/kauniyah. $\underline{\mathrm{v} 13 \mathrm{i} 2.11414}$

Hadi, I., Zamroni, Y., Tresnani, G., dan Suana, W. (2019). Survey Populasi Monyet Ekor Panjang di Wilayah Selatan Lombok Timur. BioWallacea Jurnal Ilmiah Ilmu Biologi. 5(3): 125.

DOI: 10.29303/biowall.v5i3.22

Halim, Reza. (2019). Kepadatan Populasi dan Preferensi Makan Monyet Ekor Panjang (Macaca fascicularis) di Kawasan Benteng Indra Patra sebagai Referensi Mata Kuliah Ekologi Hewan. Skripsi. Banda Aceh: Fakultas Tarbiyah dan Keguruan Universitas Islam Negeri ArRaniry.

Nabilah, H., Sjahfirdi, L., dan Prameswari, W. (2019). Pengaruh Kondisi Vasektomi pada Perilaku Reproduksi Monyet Ekor Panjang (Macaca fascicularis) di Yayasan Inisiasi Alam Rehabilitasi Indonesia Bogor. Jurnal $A L$ AZHAR INDONESIA SERI SAINS DAN TEKNOLOGI. 4(3): 126. http://dx.doi.org/10.36722/sst.v4i3 .282

Nugraha, E., Y., Wandia, I, N., dan Soma, I, G. (2018) Variasi Genetik Populasi Monyet Ekor Panjang (Macaca fascicularis) di Pulau Nusa Penida Klungkung Bali. Jurnal Veteriner. 19(4): 532.
DOI:

10.19087/jveteriner.2018.19.4.53 1

Novantica, A., Kusdiana, A., dan Pranata, O, H. (2020). Buku Cerita Tempat Bersejarah "Plangon" sebagai Sumber Belajar Kearifan Lokal untuk Anak Sekolah Dasar. PEDADIDAKTIKA: JURNAL ILMIAH PENDIDIKAN GURU SEKOLAH DASAR. 7(3): 171. http://ejournal.upi.edu/index.php/p edadidaktika/index

Rizaldy, M., R., Haryono, T., dan Faizah, U. (2016). Aktivitas Makan Monyet Ekor Panjang (Macaca fascicularis) di Hutan Nepa Kabupaten Sampang Madura. Lentera Bio Berkala Ilmiah Biologi. 66-67.

https://ejournal.unesa.ac.id/index. php/lenterabio

Sandy, Syah, R., O. (2018). Pemanfaatan Kampoeng Batja sebagai Destinasi Wisata Edukasi di Kabupaten Jember. Jurnal Sadar Wisata. 1(1): 56. DOI: 10.32528/sw.v1i1.1818

Sembiring, R., P., Setiawan, A., dan Darmawan, A. (2016). Penyebaran dan Kelimpahan Populasi Monyet Ekor Panjang (Macaca fascicularis) di Cagar Alam Sibolangit. Jurnal Sylva Lestari. 4(3): 47.

DOI: $10.23960 / \mathrm{jsl} 3447-58$

Syah, M., J. (2020). Long-Tailed Macaques (Macaca fascicularis)

Bio-Lectura: Jurnal Pendidikan Biologi, Vol 8, No 2,Oktober 2021 
and Humans Interactions in Grojogan Sewu Natural Park (TWA GS) Karanganyar Regency Central Java Province. Al-Hayat: Journal of Biology and Applied Biology. 3(1): 31.

DOI:10.21580/ah.v3i1.6069

Siswoyo, S., Nuryanto, dan Mardiana, R. (2019). Arsitektur Masjid Sunan Gunung Jati Cirebon sebagai Akulturasi Budaya Islam, Jawa, dan Cina. Jurnal Lingkungan Binaan Indonesia. 8(1): 59.

https://doi.org/10.32315/jlbi.8.1.5 $\underline{6}$

Tan, T., Xia, L., Tu, K., Tang, J., Yin, S., Dai, L., Lei, P., dan Xie, D. (2018). Improved Macaca fascicularis Gene Annotation Reveals Evolution of Gene Expression Profiles in Multiple Tissues. BMC Genomics. 19(1): 787.

https://doi.org/10.1186/s12864$\underline{018-5183-y}$ 